\title{
輸入冷凍家禽肉のサルモネラ污染に関する調査研究
}

(昭和 48 年 9 月 14 日受理)

$\begin{array}{ccccc}\text { 鈴 } & \text { 昭* 河 西 勉* } \\ \text { 小 沼 博 隆* 高 山 澄 江* }\end{array}$

\section{Studies on Salmonella Contamination of Imported Frozen Poultry Meat}

\author{
Akira Suzuki, Tsutomu Kawanishi, Hirotaka Konuma and Sumie TaKayama
}

(National Institute of Hygenic Sciences: 18-1, Kamiyoga 1-chome, Setagaya-ku, Tokyo)

Isolation and identification of Salmonella types were carried out on 1903 lots, or 6523 samples, of poultry meat imported into Japan over a 15-month period from July, 1971, to October, 1972. The following results were obtained.

1) The rate of Salmonella contamination of imported poultry meat varied with the exporting country and the kind of domestic fowls. The average rate of such contamination was 10.3 and $24.2 \%$ as determined by samples and lots, respectively.

2) The rate varied greatly with the exporting country. It was close to the average positive rate of samples for the poultry meat imported from the United States (10.7\%) and China (9.3\%). It was rather higher for that imported from New Zealand (44.4\%), the Netherlands (28.5\%), France (26.7\%), and Canada (17.6\%), whereas lower for that imported from Denmark (3.8\%).

3) When determined by the kind of poultry, the average rate of contamination in samples was $10.3 \%$ for chicken and $10.6 \%$ for meat of the other poultry than the chicken.

4) When determined by the portion of chicken, the rate of contamination was about $60 \%$, or the highest, in the "communited" portion.

5) Isolated organisms were classified into $O$ antigen groups and sero types. A total of 32 types were detected and classified into the $\mathrm{C}_{1}$ group (42.8\%), B group (29.0\%), and E group (15.8). The first 10 types of them are listed in the decreasing order of frequency as follows: S. infantis, S. anatum, S. typhimurium, S. potsdam, S. thompson, S. heidelberg, S. saint-paul, S. kottbus, S. enteritidis, and S. derby. This pattern of Salmonella types was clealy different from that of horse or kangaroo meat.

6) The pattern of Salmonella types detected from poultry meat imported from the United States and some European countries was found to be nearly similar, while there was a marked difference in that from China.

(Received September 14, 1973)

\section{まえがき}

我々は, さきに馬肉, カンガル一肉を中心とした輸入

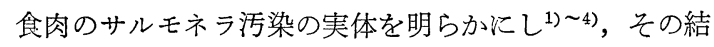
果, 輸入食肉によって我が国に搬入されつつあるサルモ ネラは, 我が国のサルモネラ食中毒の菌型の国際化に大

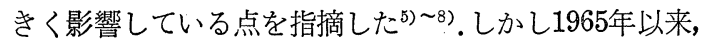
我が国のサルモネラ食中毒起因菌型の上位にランクされ

* 国立衛生試験所
ている S. heidelberg は，輸入食肉からはわずかに 1 2 例検出されたにすぎず，また輸入食肉のサルモネラ菌 型のベスト 5 に毎年ランクされていた S. minnesota, S. goodによる食中毒の報告がいまだないこと，またこ れまで圧倒的に主役の地位を占めていた S. enteritidis が輸入食肉では70余菌型中40位を占めていたことなど, いくつかの疑問の残ることを指摘し，このらちの三，三 の疑点については, 特に輸入家禽肉のサルモネラ污染の 
Table 1. Annual Amounts of Imported Chicken Meats

\begin{tabular}{|c|c|c|c|c|}
\hline & 1968 & 1969 & 1970 & $\begin{array}{c}1971 \\
(\operatorname{Jan} . \sim \text { Sept. })\end{array}$ \\
\hline China & 1,635 & 1,664 & 1,445 & 1,738 \\
\hline USA & 6,265 & 6,161 & 3,972 & 4,177 \\
\hline Denmark & 3,683 & 4,877 & 1,024 & 2,227 \\
\hline France & 36 & 19 & - & 30 \\
\hline Poland & 585 & 254 & 30 & 46 \\
\hline Rumania & 60 & 363 & 129 & - \\
\hline Netherland & 94 & 379 & 123 & 989 \\
\hline Canada & 4 & 5 & - & 1,385 \\
\hline Bulgaria & 1,705 & 3,205 & 930 & 2,568 \\
\hline Hangary & 1,385 & 2,681 & 1,979 & 1,725 \\
\hline Others & 6 & 38 & 60 & - \\
\hline Total & 15,257 & 19,646 & 9,692 & 14,885 \\
\hline
\end{tabular}

(unit. ton) (by Annual Report of Customs in Department of Finance)

Table 2. Comparison of Contamination Rate of Serological Group of Salmonella Isolated from Imported Poultry Meats Sourced in Different Districts

(July 1971 Oct. 1972)

\begin{tabular}{|c|c|c|c|c|c|c|c|}
\hline \multicolumn{3}{|c|}{ Continent } & America & China & Europe & Others & Total \\
\hline \multicolumn{3}{|c|}{ No. of tested lots } & 802 & 736 & 355 & 10 & 1,903 \\
\hline \multicolumn{3}{|c|}{ No. of positive lots } & 208 & 168 & 81 & 4 & 456 \\
\hline \multicolumn{3}{|c|}{ Percentage of positive lots } & 25.9 & 22.1 & 22.8 & 40.0 & 24.0 \\
\hline \multirow{3}{*}{\multicolumn{3}{|c|}{$\begin{array}{l}\text { No. of tested samples } \\
\text { No. of positive samples } \\
\text { Percentage of positive samples }\end{array}$}} & 2,881 & 2,219 & 1,391 & 32 & 6,523 \\
\hline & & & 320 & 207 & 136 & 10 & 673 \\
\hline & & & 11.1 & 9.3 & 9.8 & 31.3 & 10.3 \\
\hline \multirow{14}{*}{ 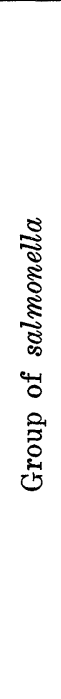 } & B group & $*$ & 119 & 8 & 61 & 7 & 195 \\
\hline & & $* *$ & 37.2 & 3.9 & 44.9 & 70.0 & 30.0 \\
\hline & $\mathrm{C}_{1}$ group & $*$ & 125 & 98 & 63 & 2 & 288 \\
\hline & & $* *$ & 39.1 & 47.3 & 46.3 & 20.0 & 42.8 \\
\hline & $\mathrm{C}_{2}$ group & $*$ & 45 & 2 & 4 & - & 51 \\
\hline & & $* *$ & 14.1 & 1.0 & 2.9 & - & 7.6 \\
\hline & D group & $*$ & 11 & 2 & 7 & - & 20 \\
\hline & & $* *$ & 3.4 & 1.0 & 5.2 & - & 3.0 \\
\hline & E group & $*$ & 8 & 97 & 1 & - & 106 \\
\hline & & $* *$ & 2.5 & 46.9 & 0.7 & - & 15.8 \\
\hline & Further group & $*$ & 9 & - & - & 1 & 10 \\
\hline & & $* *$ & 2.8 & - & - & 10.0 & 1.5 \\
\hline & Arizona & $*$ & 3 & - & - & - & 3 \\
\hline & & $* *$ & 0.9 & - & - & - & 0.5 \\
\hline
\end{tabular}

* No. of positive samples ** Percentage of positive samples 







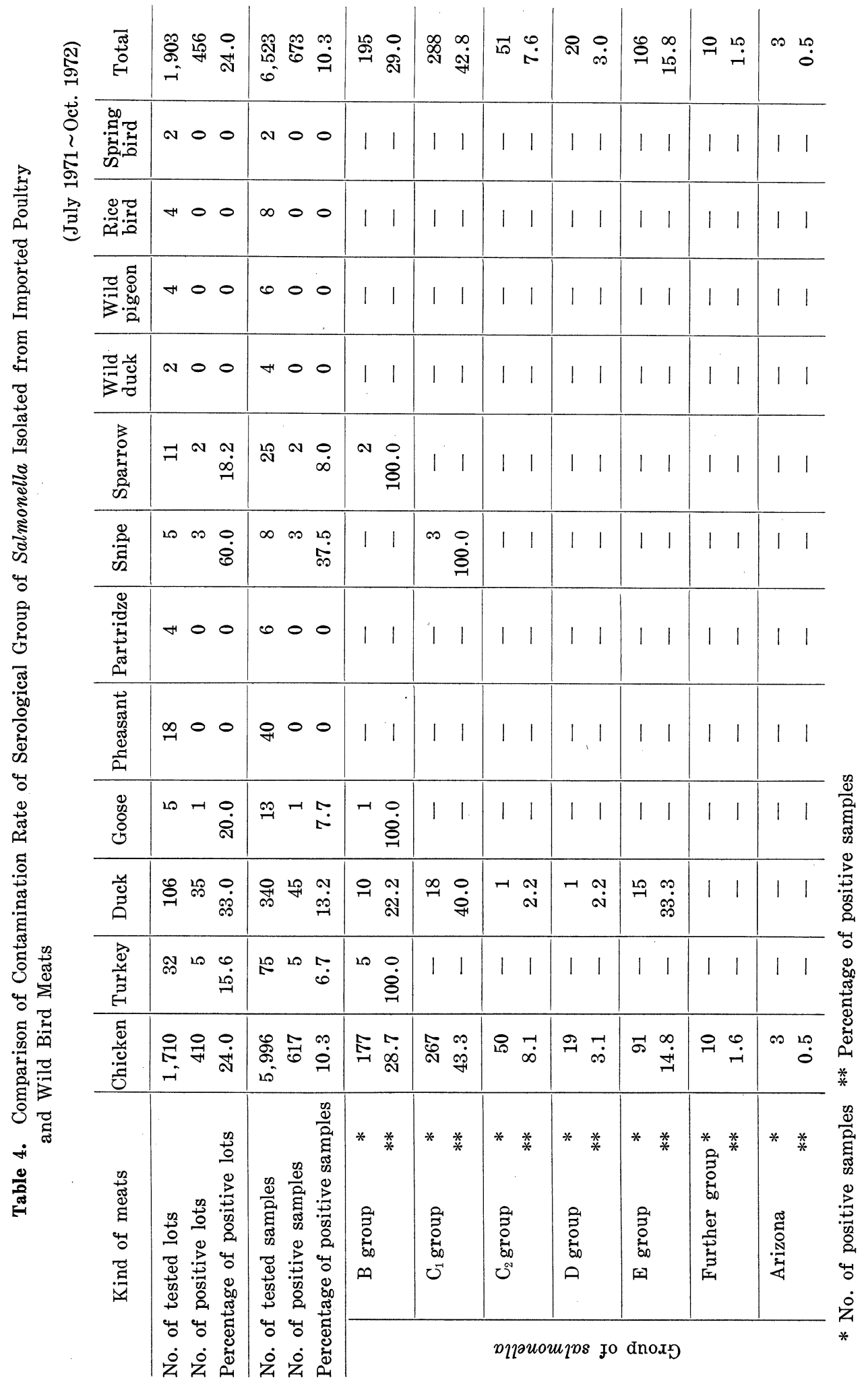


実体を究明することにより，あるいは解明できるかも知 れないと考えた。

近年我が国においても鶏肉の消費の増大に伴い輸入量 も急激に増加し，(Table 1 参照）また我が国に拈けるブ ロイラーの生産も年々大型化の傾向をたどっている.ブ

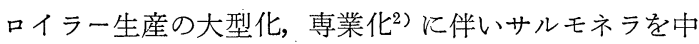
心とした衛生上の問題点は生産, 消費両面にわたって, 再び注目をあびるに至っている ${ }^{9)}$ 12).

しかるに我が国に輸入される家禽肉のサルモネラ污染 の実体についてはいまだなお十分明らかにされていな い. そこで我々の研究室に沶いても1971年以降輸入食品 検査強化の一環として, 冷涷輸入家禽肉のサルモネラ検 査を輸入時の重要検査項目に加え, 爾来今日に至るまで 検査を続行中であるが，1971から1972年の間の約15か月 余の調查研究によりほぼその全容を把握し, 若干の新知 見を得ることができたので，その結果について報告す る.

\section{実験方法}

検体の収集：検体は輸入検查品として, 小樽，東 京, 横浜, 大阪, 神戸の各港に駐在する厚生省の検査官 により, 収去, 送付されたもので, 総数 1903 ロット, 6523検体である.

サルモネラの分離, 同定法: サルモネラの分離, 同 定法はすでに報告した馬肉を中心とした検査法に準じ $た^{1) \sim 4)}$.

\section{結果および考察}

\section{A. 0 血清の群別でみた污染状況}

\section{1. 輸入国別によるサルモネラ污染状況}

まず翰入国別によりサルモネラ污染がどのような相違 を示すかをみた. その結果を Table 3 に示す.

主要輸入国のうち，ロット別で陽性率の高いものから 順にあげると，オランダ $57.5 \%$, カナダ $53.1 \%$, ブルガ リヤ35.4\%, アメリカ $24.8 \%$, 中国 $22.1 \%$ ，ハンガリー $19.0 \%$ ，デンマーク $8.6 \%$ で平均 $24.2 \%$ であった。 これ を検体別に細分してみると，オランダ $28.5 \%$, カナダ $17.6 \%$ ，ブルガリア $13.5 \%$ ，アメリカ $10.7 \%$ ，ハンガリ 一,デンマークはともに数\%以下で平均 $10.3 \%$ であっ た。このように程度の差こそあれすでに我が国を含め

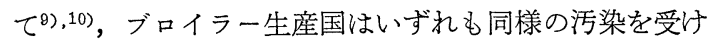
ているものと考えられる. しかしこれらの成績は, 当室 に送付された検体についての結果から集計したものであ って，同一検体でもその污染状態には著しくバラッキが

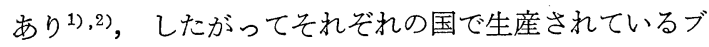
ロイラーの平均的污染率を必ずしも示すものではなく, 現在のところいずれの国においても予想外にサルモネラ 污染はひどく，その程度は大同小異 ${ }^{18), 17)}$ であるとみる ベきであろう.

污染率を分離菌に対する 0 血清による群別でみると， $\mathrm{C}_{1}$ 群が約半数を占め, 輸入国によっては過半数を占め
るものもあった. 次いで $\mathrm{B}$ 群が約 $30 \%$ を占め, $\mathrm{C}_{1}$ 群同 様, 国によっては $80 \%$ これによって占有されていたも のがあった.

国別により最も特徵的な結果を示したのは，アメリカ

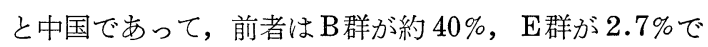
あったのに対し, 後者はB群 $4 \%$, E群が $46.9 \%$ と対照 的な様相を示していたことである.

家禽肉由来菌に $\mathrm{C}_{1}$ 群が過半数を占めていたことは, す でに我々が報告した馬肉やカンガルー肉由来菌が $\mathrm{E}$ 群と その他の群で過半数を占めていた成績 ${ }^{1) \sim 4)}$ とを比較する までもなく, すでに渡辺 ${ }^{9)}$ (11), 佐藤 ${ }^{12)}$ らも述べている ように $\mathrm{C}_{1}$ 群は家禽類に多い菌群と考穴られる.

2. 輸入国の属する大陸別によるサルモネラ污染状況

輸入国の属する大陸を, アメリカ大陸, ヨーロッパ大 陸, 中国大陸, その他の大陸の四つに分別して, その污 染率をみると Table 2 に示すと㧤りである.

Table 5. Summarized Data Serological Group of Salmonella Isolated Poultry and Wild Bird Meats

(July 1971 Oct. 1972)

\begin{tabular}{|c|c|c|c|c|}
\hline \multicolumn{3}{|c|}{ Kind of meats } & Poultry & $\begin{array}{l}\text { Wild } \\
\text { bird }\end{array}$ \\
\hline \multirow{3}{*}{\multicolumn{3}{|c|}{$\begin{array}{l}\text { No. of tested lots } \\
\text { No. of positive lots } \\
\text { Percentage of positive lots }\end{array}$}} & 1,875 & 28 \\
\hline & & & 451 & 5 \\
\hline & & & 24.0 & 17.8 \\
\hline \multirow{3}{*}{\multicolumn{3}{|c|}{$\begin{array}{l}\text { No. of tested samples } \\
\text { No. of positive samples } \\
\text { Percentage of positive samples }\end{array}$}} & 6,470 & 53 \\
\hline & & & 668 & 5 \\
\hline & & & 10.3 & 9.4 \\
\hline \multirow{14}{*}{ 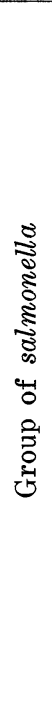 } & \multirow[t]{2}{*}{ B group } & $*$ & 193 & 2 \\
\hline & & $* *$ & 28.8 & 40.0 \\
\hline & \multirow[t]{2}{*}{$\mathrm{C}_{1}$ group } & $*$ & 285 & 3 \\
\hline & & $* *$ & 42.7 & 60.0 \\
\hline & \multirow[t]{2}{*}{$\mathrm{C}_{2}$ group } & $*$ & 51 & - \\
\hline & & $* *$ & 7.6 & - \\
\hline & \multirow[t]{2}{*}{ D group } & $*$ & 20 & - \\
\hline & & $* *$ & 3.0 & - \\
\hline & \multirow[t]{2}{*}{ E group } & $*$ & 106 & - \\
\hline & & $* *$ & 15.9 & 一 \\
\hline & \multirow[t]{2}{*}{ Further } & $*$ & 10 & - \\
\hline & & $* *$ & 1.5 & - \\
\hline & \multirow{2}{*}{ Arizona } & $*$ & 3 & - \\
\hline & & $* *$ & 0.5 & - \\
\hline
\end{tabular}

* No. of positive samples

** Percentage of positive samples 


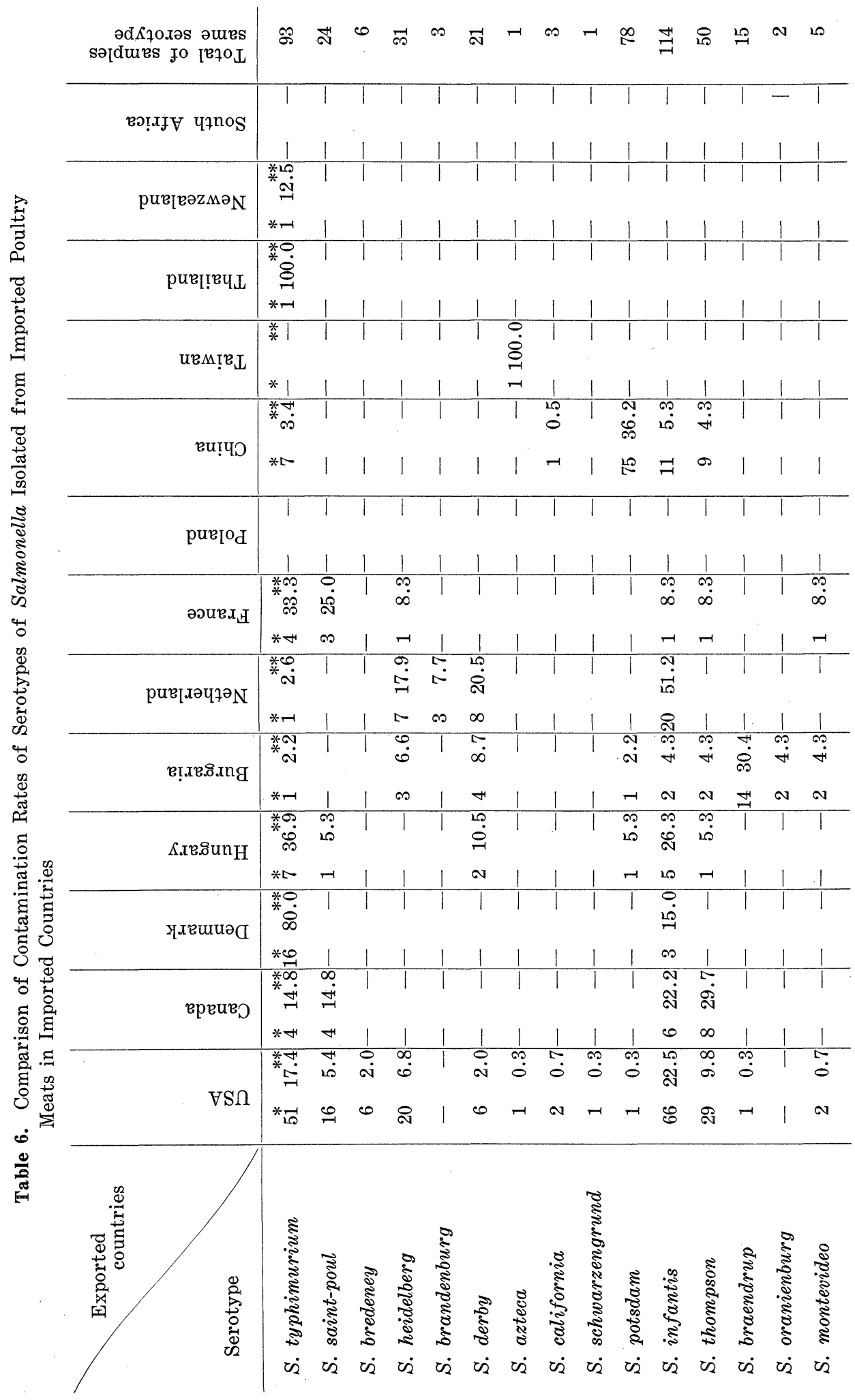




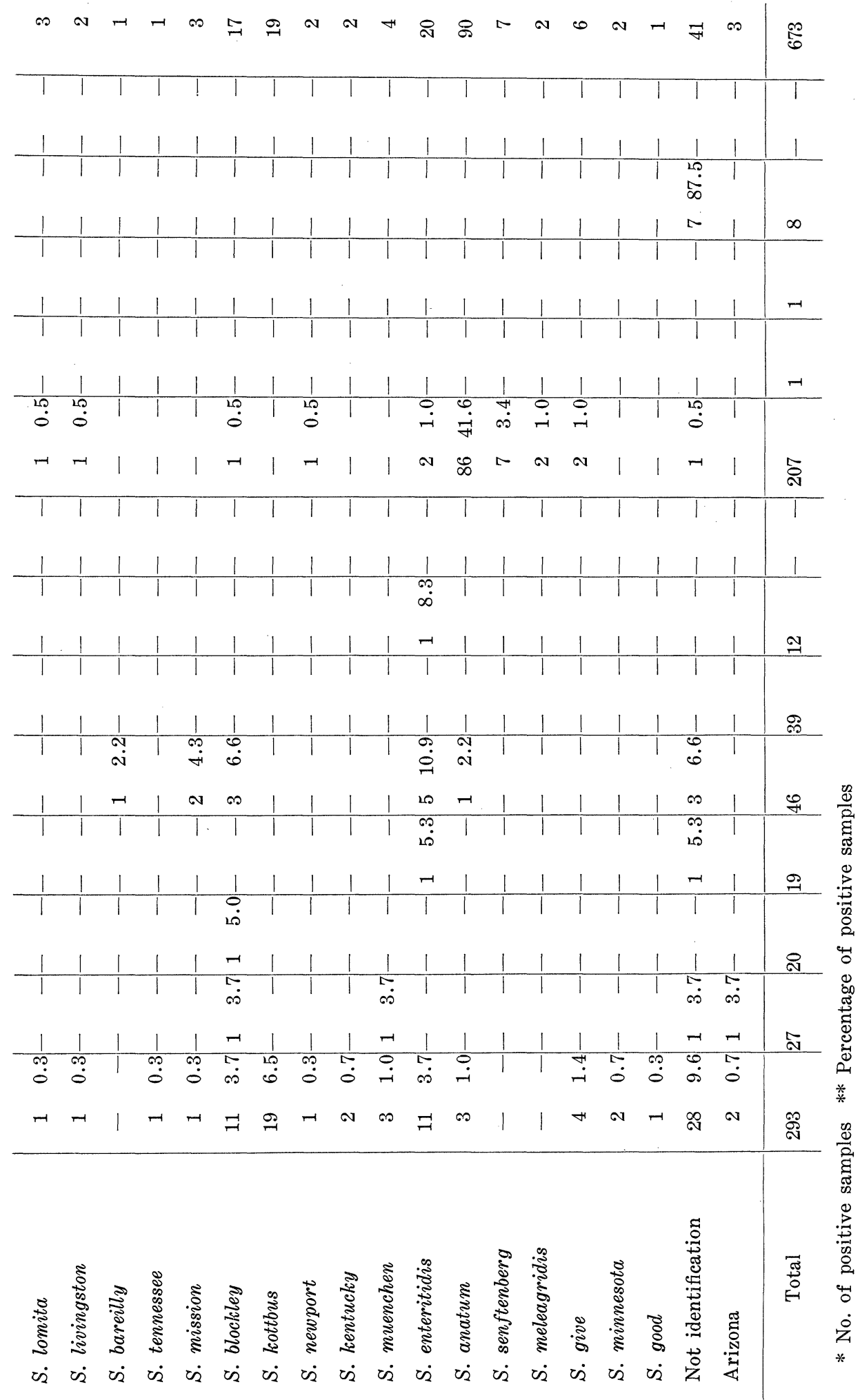




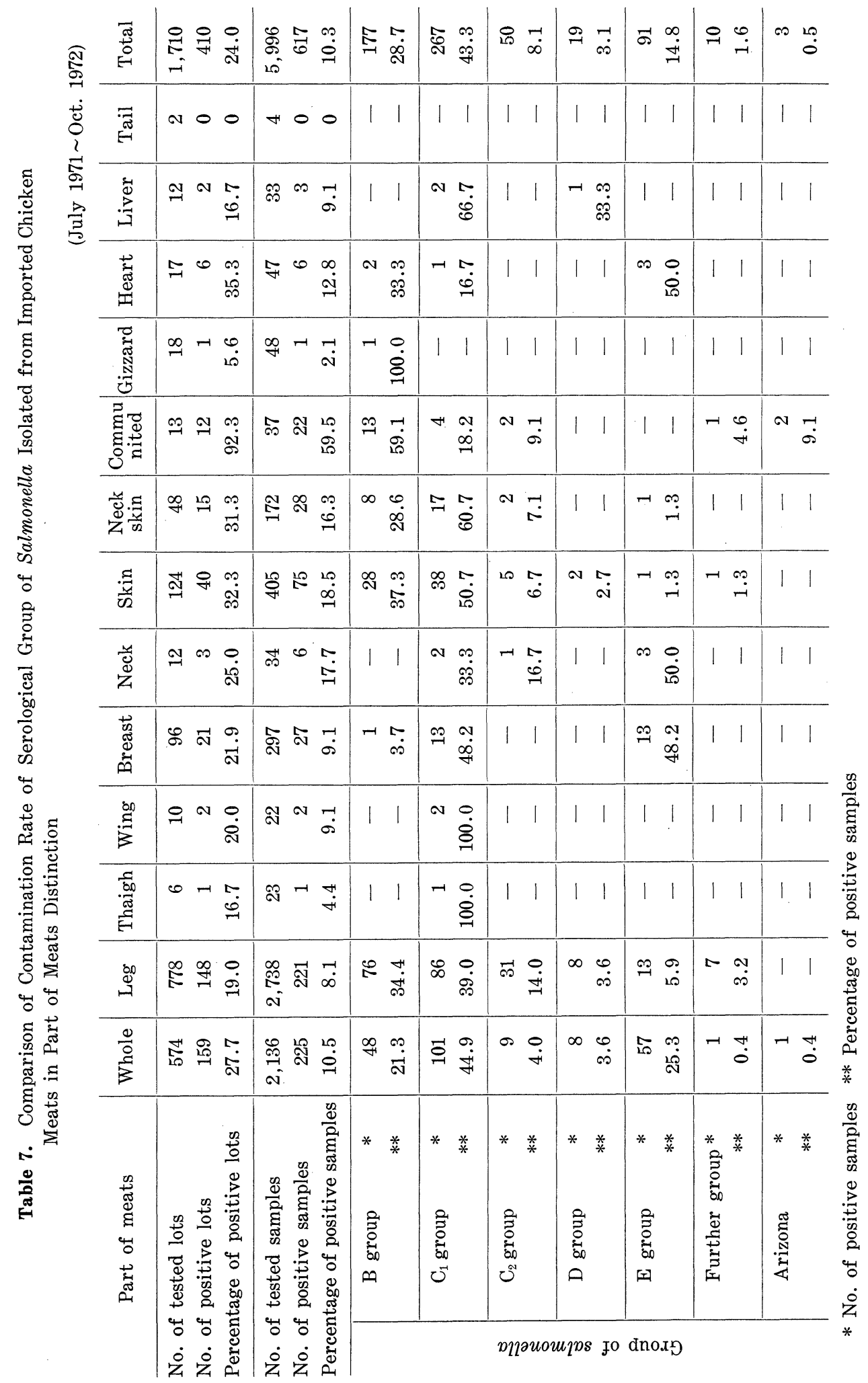


ロット別では, アメリカ大陸 25.9\% (208/802), ヨー ロッパ大陸22.8\% (81/355), 中国大陸22.1\% (168/736) でよく相似した結果を示していた。 しかしその污染率を $\mathrm{O}$ 血清の群別でみると, 明らかにアメリカ大陸と中国大 陸とでは，すでにアメリカと中国との関係で述べたよう
に対照的な結果を示していた.この両国の関係の相違は 後述する菌型別でさらに明りょらとなる.

このことは從来アメリカ大陸と中国大陸とが食肉やそ の他の輸出入食品などのようなサルモネラの搬入の役割 を果すと考えられるよらなものを通しての交流が比較的

Table 8. Comparison of Serotypes of Salmonella Isolated from Imported Poultry Meats Sourced in Different Districts

\begin{tabular}{|c|c|c|c|c|c|c|c|c|c|}
\hline $\begin{array}{l}\text { Continent } \\
\text { Serotype }\end{array}$ & & merica & & China & & Surope & & Others & $\begin{array}{l}\text { Total of samples } \\
\text { same serotype }\end{array}$ \\
\hline S. typhimurium & 55 & $\begin{array}{c}\%(\%) \\
17.2(59.1)\end{array}$ & $\stackrel{*}{7}$ & $\begin{array}{l}\%(\%) \\
3.4\left(\begin{array}{c}\% .5 \\
\text { ( }\end{array}\right.\end{array}$ & 29 & $\begin{array}{cc}\% & (\%) \\
21.3(31.2)\end{array}$ & $\stackrel{*}{2}$ & $\begin{array}{cc}\% & (\%) \\
20.0( & 2.2)\end{array}$ & 93 \\
\hline S. saint-poul. & 20 & $6.3(83.3)$ & - & - & 4 & $2.9(16.7)$ & 一 & - & 24 \\
\hline S. bredeney & 6 & $1.9(100.0)$ & - & - & - & - & - & - & 6 \\
\hline S. heidelberg & 20 & $6.3(64.5)$ & - & - & 11 & $8.0(35.5)$ & - & - & 31 \\
\hline S. brandenburg & - & - & - & 一 & 3 & $2.2(100.0)$ & - & - & 3 \\
\hline S. derby & 6 & $1.9(28.6)$ & 一 & - & 14 & $10.3(66.7)$ & 1 & $10.0(\quad 4.8)$ & 21 \\
\hline S. azteca & 1 & $0.3(100.0)$ & 一 & - & - & - & - & 一 & 1 \\
\hline S. california & 2 & $0.6(66.7)$ & 1 & $0.5(33.3)$ & - & - & - & - & 3 \\
\hline S. schwarzengrund & 1 & $0.3(100.0)$ & 一 & - & - & - & - & - & 1 \\
\hline S. potsdam & 1 & $0.3(1.3)$ & 75 & $36.2(96.2)$ & 2 & $1.5(2.6)$ & - & - & 78 \\
\hline S. infantis & 72 & $22.7(63.2)$ & 11 & $5.3(\quad 9.7)$ & 31 & $22.8(27.2)$ & $一$ & - & 114 \\
\hline S. thompson & 37 & $11.6(74.0)$ & 9 & $4.3(18.0)$ & 4 & $2.9(8.0)$ & - & - & 50 \\
\hline S. braenderup & 1 & $0.3(\quad 6.7)$ & - & - & 14 & $10.3(93.3)$ & - & - & 15 \\
\hline S. oranienburg & - & - & 一 & 一 & 2 & $1.5(100.0)$ & - & 一 & 2 \\
\hline S. montevideo & 2 & $0.6(40.0)$ & - & - & 3 & $2.2(60.0)$ & - & - & 5 \\
\hline S. lomita & 2 & $0.6(66.7)$ & 1 & $0.5(33.3)$ & - & - & - & - & 3 \\
\hline S. livingstone & 1 & $0.3(50.0)$ & 1 & $0.5(50.0)$ & - & - & - & - & 2 \\
\hline S. bareilly & - & - & - & - & 1 & $0.7(100.0)$ & - & - & 1 \\
\hline S. tennessee & 1 & $0.3(100.0)$ & - & - & - & - & - & - & 1 \\
\hline S. mission & 1 & $0.3(33.3)$ & 一 & 一 & 2 & $1.5(66.7)$ & - & - & 3 \\
\hline S. blockley & 12 & $3.8(70.6)$ & 1 & $0.5(\quad 5.9)$ & 4 & $2.9(23.6)$ & - & - & 17 \\
\hline S. kottbus & 19 & $5.9(100.0)$ & - & 一 & - & - & - & 一 & 19 \\
\hline S. newport & 1 & $0.3(50.0)$ & 1 & $0.5(50.0)$ & - & 一 & - & - & 2 \\
\hline S. kentucky & 2 & $0.6(100.0)$ & - & - & - & - & - & 一 & 2 \\
\hline S. muenchen & 4 & $1.3(100.0)$ & - & - & - & - & - & - & 4 \\
\hline S. enteritidis & 11 & $3.4(55.0)$ & 2 & $1.0(10.0)$ & 7 & $5.1(35.0)$ & - & - & 20 \\
\hline S. anatum & 3 & $0.9(\quad 3.3)$ & 86 & $41.6(95.6)$ & 1 & $0.7\left(\begin{array}{ll}1.1\end{array}\right)$ & - & - & 90 \\
\hline S. senftenberg & - & - & 7 & $3.4(100.0)$ & - & - & - & - & 7 \\
\hline S. meleagridis & - & - & 2 & $1.0(100.0)$ & - & - & - & - & 2 \\
\hline S. give & 4 & $1.3(66.7)$ & 2 & $1.0(33.3)$ & - & - & - & - & 6 \\
\hline S. minnesota & 2 & $0.6(100.0)$ & 一 & - & - & - & 一 & 一 & 2 \\
\hline S. good & 1 & $0.3(100.0)$ & - & - & - & - & - & - & 1 \\
\hline Not identification & 29 & $9.1(70.7)$ & 1 & $0.5(2.4)$ & 4 & $2.9(9.8)$ & 7 & $70.0(17.0)$ & 41 \\
\hline Arizona & 3 & $0.9(100.0)$ & - & - & - & - & - & - & 3 \\
\hline Total & 320 & 100.0 & 207 & 100.0 & 136 & 100.0 & 10 & 100.0 & 673 \\
\hline
\end{tabular}

* No. of positive samples \% percentage to total positive samples

(\%) percentage to total of same serotype 
少なかったためではなかららかと考えられる.

3. 鵎肉, 七面鳥肉, あひる肉, がちょう肉など肉種 別によるサルモネラ污染状況

鶏肉, 七面鳥肉, あひる肉, がちょう肉など肉種別に よって，サルモネラ污染率がどのように異なるかを検討 し，その結果を Table 4 に示した。

ロット別では,鶏肉24.0\% (410/1710), 七面鳥肉 $15.6 \%$ (5/32)，あひる肉 $33.0 \%(35 / 106)$ であひる肉の方が前二 者より污染率は高かった。 この傾向は検体別でも同様で あった。このような点に関して，すでに Prost ら ${ }^{26)}$ 1963年アメリカから西ドイツに輸入したブロイラーにつ いて報告している，また我が国に拈けるブロイラーにつ いての調査結果も大体一致した傾向を示している10),13).

あひる肉が鶏肉より一般にサルモネラ污染が高率であ ることについては，すでに多くの報告があるが18) 20)， 七面鳥肉 ${ }^{21)}, 22$,25)，がちょう肉，きじ肉などにも広くサ ルモネラ污染のあることが報告されている ${ }^{23), 24)}$. 全 般 的にみて, 獣肉に比較して家禽肉のサルモネラ污染の方 がさらに濃厚であると考えられる27).

\section{4. 家禽肉と野鳥肉のサルモネラ污染の比較}

人工的に一定の地域，環境下，飼料などで飼育されて いる家禽の肉と在野性の野鳥の肉では，サルモネラ污染 に相違が認められるのではないかと考えて検討したとこ ろ，ロット別では前者 $24.0 \%$ ，後者 $17.8 \%$ ，検体別で は前者 $10.3 \%$, 後者 $9.4 \%$ と大差のない結果であった (Table 5).

しかし家禽肉からは $\mathrm{C}_{1}$ 群, $\mathrm{B}$ 群, $\mathrm{E}$ 群, $\mathrm{C}_{2}$ 群, $\mathrm{D}$ 群，その他の群と多彩な菌型が検出されたのに対し，野 鳥肉からは $\mathrm{B}$ 群と $\mathrm{C}_{1}$ 群のみでこの点から考えても $\mathrm{C}_{1}$ 群，B群は鳥類とより深い何らかの相関性を持っている のではないかと推察される。一定の人工的環境と飼料に より飼育された家禽類と在野性の野鳥とでは, 前者にサ ルモネラ污染が濃厚であることは十分想像でさるところ
であるが29)，野鳥類にも広くサルモネラは分布し，すで にキジ, カモメ23),24), カナリヤ, オウム, ツル, サギ27) などからも検出されている，今回の我々の調查でも家禽 類と同様の污染率で，すでに野外全般にサルモネラが高 濃度に污染していることが確認された。

\section{5. 鵎肉の部位別によるサルモネラ污染状況}

検体数の最も多かった鶏肉について，肉の部位別によ る污染状態について検討した。その結果を Table 7 に 示した.

ロット別では，〈ず肉のすり身 (communited) の污染 が最も高く $(92.3 \%)$, 次いで heart $(35.3 \%)$, skin $(32.3 \%)$, neck skin $(31.3 \%)$, whole $(27.2 \%)$, neck $(25.0 \%)$, breast $(21.9 \%)$, wing $(20.0 \%)$ の順であっ た。 また検体別では陽性率がロット別の約 $1 / 2$ でその順 位も同様の傾向であった.

これをＯ血清群別でみると，whole， leg, skinなどは $\mathrm{C}_{1}$ 群が最も多く, 次いで $\mathrm{B}$ 群であったが communited はその約 $60 \%$ が B 群で占め， $\mathrm{C}_{1}$ 群は比較的低率であっ た.

このようにいずれの部位からも高率にサルモネラが検 出されたことは，処理場に括けると殺，解体，製品化す る過程での污染と, その工程の污染源となる鷄の羽毛, 体表のサルモネラ污染，さらには鶏の䔬便による影響な どによって高度にその処理場全般がサルモネラ污染を受

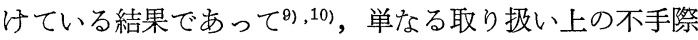
による影響だけではないと考えられる。

以上の結果は, 検出されたサルモネラを群別で検討し たものであるが，菌型別にどのような特徵的傾向を示す かをみたのが Table 6 以下に示した結果である.

B. 菌型別にみたサルネラ污染状況

1. 輸入国別による菌型別污染率

輸入国によってどのような菌型のものによって占めら れているかる検討した。 その結果は Table 6 に示した.

Table 9. Occurrence of Serotype of Salmonella Isolated from Imported Poultry Meats Sourced in Different Districts

\begin{tabular}{c|l|l|l|l} 
Continent & \multicolumn{1}{|c|}{ America } & \multicolumn{1}{|c|}{ China } & \multicolumn{1}{|c}{ Europe } & \multicolumn{1}{|c}{ Others } \\
\cline { 1 - 2 } Occurrence & S. infantis & S. anatum & S. infantis & S. typhimurium \\
2 & S. typhimurium & S. potsdam & S. typhimurium & S. derby \\
3 & S. thompson & S. infantis & S. derby & \\
4 & S. saint-poul & S. thompson & S. braenderup & \\
5 & S. heidelberg & S. typhimurium & S. heidelberg & \\
6 & S. hottbus & S. senftenberg & S. enteritidis & \\
7 & S. blockley & S. enteritidis & S. saint-poul & \\
8 & S. enteritidis & S. meleagridis & S. thompson & \\
9 & S. bredeney & S. give & S. blockley & \\
10 & S. derby & S. blockley & S. brandenburg &
\end{tabular}


検体数の最も多かったアメリカからのものでは, S. infantis $22.5 \%$, S. typhimurium $17.5 \%$, S. thompson $9.8 \%, S$. heidelberg $6.8 \%$, S. kottbus $6.5 \%$, S. saint-paul 5.4\%, S. enteritidis $3.7 \%$ な ど27菌型が検出され，いずれもすでにアメリカで高頻度 に検出されている菌型である16).

カナダからのものでは, S. thompson $29.7 \%, S$. infantis $22.2 \%$, S. typhimurium, S. saint-paul 各14.8\%などで高頻度に検出される菌型はアメリカに類 似していたが，検出された菌型数はわずかに 6 菌型であ った.
デンマークからのものでは, S. typhimurium が $80 \%$ を占めていた。

ハンガリーからのものでは, S. typhimurium $36.9 \%$, S. infantis $26.3 \%$, S. derby $10.5 \%$, S. sain-paul, S. potsdam, S. thompson, S. enteritidis 各5.3\%であった.

ブルガリヤからのものでは, S. braendrup 30.4\%, S. enteritidis $10.9 \%$, S. derby $8.7 \%$, S. blockley $6.6 \%$ な゙をはじめ14菌型が検出された.

オランダからのものでは, S. infantis $51.2 \%, S$. derby $20.5 \%, S$. heidelberg $17.9 \%$ など 5 菌型が検

Table 10. Comparison of Serotype of Salmonella Isolated from Imported Poultry and Wwld Bird Meats

\begin{tabular}{|c|c|c|c|c|c|c|}
\hline $\begin{array}{l}\text { Kind of meats } \\
\text { Serotype }\end{array}$ & Chicken & Turkey & Duck & Goose & Snipe & Sparrow \\
\hline $\begin{array}{l}\text { S. typhimurium } \\
\text { S. saint-poul } \\
\text { S. bredeney } \\
\text { S. heidelberg } \\
\text { S. derby } \\
\text { S. azteca } \\
\text { S. california } \\
\text { S. schwarzengrund } \\
\text { S. potsdam } \\
\text { S. infantis } \\
\text { S. thompson } \\
\text { S, braenderup } \\
\text { S. oranienburg } \\
\text { S. montevideo } \\
\text { S. lomita } \\
\text { S. livingstone } \\
\text { S. bareilly } \\
\text { S. tennessee } \\
\text { S. mission } \\
\text { S. blockley } \\
\text { S. kottbus } \\
\text { S. newport } \\
\text { S. kentucky } \\
\text { S. muenchen } \\
\text { S. enteritidis } \\
\text { S. anatum } \\
\text { S. senftenberg } \\
\text { S. meleagridis } \\
\text { S. give } \\
\text { S. minnesota } \\
\text { S. good } \\
\text { Arizona } \\
\text { S. }\end{array}$ & 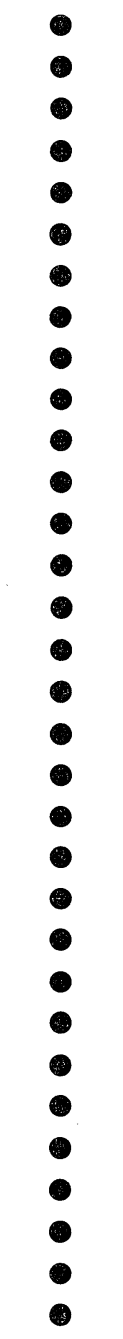 & - & 붐 & (2) & - & 0 \\
\hline
\end{tabular}


出された.

フランスからのものでは, S. typhimurium $33.3 \%$,

S. saint-paul 25.0\%, S. heidelberg, S. thompson,

S. montevideo, S. enteritidis 各8.3\%であった.

中国からのものでは, S. anatum $41.6 \%, S$. potsdam 36.2\% をはじめ14菌型が検出されたが，各
国のものに広く，しかも高頻度に検出されていた $S$. infantis はわずかに5.3\%にすぎなかった.

以上のように国によってそれぞれ優占する菌型に片寄 りが認められる菌型と，世界各国共通に認められる菌型 とに大別されるが，最も特徵的な様相を示していたの は，中国からのものであって，アメリカやヨーロッパ各

Table 11. Comparison of Serotype Salmonella Isolated from Imported Chicken Meats in Part of Meats Distinction

\begin{tabular}{|c|c|c|c|c|c|c|c|c|c|c|c|c|c|c|}
\hline Serotype & $\frac{\stackrel{0}{\circ}}{3}$ & 离 & 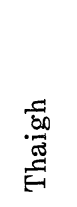 & $\stackrel{60}{\Xi}$ & 品 & ż & 㻤 & 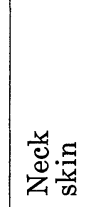 & 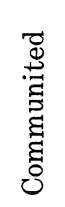 & 㶓 & 莺 & 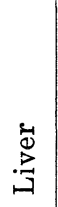 & 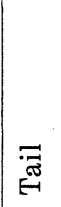 & 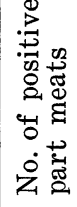 \\
\hline $\begin{array}{l}\text { S. typhimurium } \\
\text { S. saint-paul } \\
\text { S. bredeney } \\
\text { S. heidelberg } \\
\text { S. brandenburg } \\
\text { S. derby } \\
\text { S. azteca } \\
\text { S. california } \\
\text { S. schwarzengrund } \\
\text { S. potsdam } \\
\text { S. infantis } \\
\text { S. thompson } \\
\text { S. braenderup } \\
\text { S. oranienburg } \\
\text { S. montevideo } \\
\text { S. lomita } \\
\text { S. livingstone } \\
\text { S. bareilly } \\
\text { S. tennessee } \\
\text { S. mission } \\
\text { S. blockley } \\
\text { S. kottbus } \\
\text { S. newport } \\
\text { S. kentuky } \\
\text { S. muenchen } \\
\text { S. enteritidis } \\
\text { S. anatum } \\
\text { S. senftenberg } \\
\text { S. meleagridis } \\
\text { S. give } \\
\text { S. minnesota } \\
\text { S. good } \\
\text { Not identification } \\
\text { Arizona }\end{array}$ & 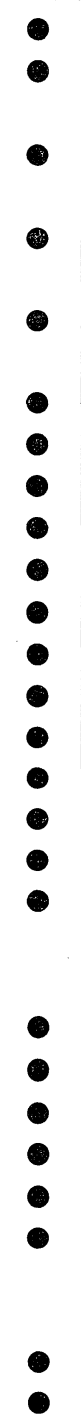 & $\begin{array}{l}0 \\
0 \\
0 \\
0 \\
0 \\
0 \\
0 \\
0 \\
0 \\
0 \\
0 \\
0 \\
0 \\
0 \\
0 \\
0 \\
0 \\
0 \\
0\end{array}$ & 0 & ? & • & - & $\begin{array}{l}0^{1} \\
- \\
- \\
0\end{array}$ & - & • & 0 & - & ? & & $\begin{array}{l}1 \\
2 \\
2 \\
1 \\
1 \\
2 \\
2 \\
3 \\
3 \\
2 \\
1 \\
2 \\
4 \\
6 \\
3 \\
2 \\
2 \\
1 \\
1 \\
5 \\
2\end{array}$ \\
\hline
\end{tabular}


国からのものとは明らかに異なり，S. anatum と $S$. potsdam でその大半を占め, 我々が輸入家离肉から検 出分離した当該菌の $95 \%$ 以上は中国産のものから分離し たものであった。このように中国とアメリカ， ヨーロッ パ各国からのものとで菌型に相違が認められたのは，す でに述べたよらに諸般の事情から比較的交流がなかった ことが，その原因ではないかと考えられる.この点, 我 が国の現状をみると，アメリカ，ヨーロッパ各国の菌型 とよく相似した様相を示しているす ${ }^{911}$.

\section{2. 輸入国の属する大陸別による主要菌型別污染率と} 分布状態

輸入国によって菌型がそれぞれ特徴的な様相を示して いたが，その国の属している大陸別にまとめた場合どの よらな様相を示すかを検討してみた。 その結果は Table 8 に示した.

アメリカ大陸からは, S. infantis $22.7 \%, S$. typhimurium 17.2\%, S. thompson $11.6 \%, S$. saint-paul, S. heidelberg 各6.3\%をはじめ27菌型が 検出され, 我々がこの調査研究で検出分離した総菌型の 約70\%はこのアメリカ系から分離したもので，このパタ ーンを我々はアメリカ型と仮称することとした。な抗 の系からのみ検出された菌型は10菌型 S. bredeney, S. azteca, S. schwarzengrund, S. tennessee, S. misson, S. kottbus, S. kentucky, S. muenchen, S. minnesota, S. good であった。 しかしこれらの菌型は既報の馬肉 (南米), カンガルー肉 (オーストラリア) からもすでに 検出されている菌型であるところからアメリカ大陸に限 局されている菌型ではない.

中国大陸からは, 中国産のその項で述べたとおりで あるが，これを中国型と仮称することとした。なおこ の系からのみ検出された菌型は S. senftenberg, S. meleagridis であった.

ヨーロッパ大陸からは， S. infantis $22.8 \%, S$. typhimurium 21.3\%, S. derby, S. braenderup 各 $10.3 \%$, S. heidelberg $8.0 \%$, S. enteritidis $5.1 \%$ をはじめ 16 菌型が検出され，これをヨーロッパ型と仮称 することとした。な抗この系からのみ検出された菌型は 3 菌型 S. brandenburg, S. oranienburg, S. bareilly であった. しかしヨーロッパ型はアメリカ型のそれによ く類似の菌型であった.

その他の大陸からは, S. typhimurium と S. derby の 2 菌型で，この菌型は世界的に広く分布している菌型 である14).

なお各大陸別に，検出された菌型のベスト10を示すと Table 9 のとおりである。

四大陸ともべスト 10 にンクされた菌型は $S$. typhimurium のみであったが，いずれかの三大陸に おいて共通してランクされた菌型は, S. infantis, S. thompson, S. derby, S. enteritidis, S. blockley, 同
様にいずれかの二大陸に共通してランクされた菌型は S. heiderberg, S. saint-paul であった.

\section{3. 鶏肉, 七面鳥肉, あひる肉などの肉種別による菌}

\section{型の分布}

鷄肉，七面鳥肉，あひる肉などの肉種別にどのような 菌型が分布しているかを検討した。

その結果は Table 10 に示した.

鷄肉からは Arizona を含めて32菌型, 七面鳥肉から は S. saint-paul の 1 菌型, あひる肉からは 7 菌型,

Table 12. Rank of Occurrence of Serotype of Salmonella Isolated from Imported Poultry and Horse etc. Meats

\begin{tabular}{|c|c|c|}
\hline \multirow{2}{*}{ Serotype } & \multicolumn{2}{|c|}{ Rank of occurrence } \\
\hline & $\begin{array}{l}\text { Poultry } \\
\text { meats }\end{array}$ & $\begin{array}{c}\text { Horse etc. } \\
\text { meats }\end{array}$ \\
\hline S. infantis & 1 & 35 \\
\hline S. anatum & 2 & 1 \\
\hline S. typhimurium & 3 & 8 \\
\hline S. potsdam & 4 & 23 \\
\hline S. thompson & 5 & 48 \\
\hline S. heidelberg & 6 & 64 \\
\hline S. saint-paul & 7 & 12 \\
\hline S. kottbus & 8 & 7 \\
\hline S. enteritidis & 9 & 49 \\
\hline S. derby & 10 & 13 \\
\hline S. blockley & 11 & - \\
\hline S. braenderup & 12 & - \\
\hline S. oranienburg & 13 & 4 \\
\hline S. senfienberg & 14 & 50 \\
\hline S. bredeney & 15 & 14 \\
\hline S. give & 16 & 22 \\
\hline S. montevideo & 17 & 11 \\
\hline S. muenchen & 18 & 17 \\
\hline S. california & 19 & - \\
\hline S. lomita & 20 & 31 \\
\hline S. mission & 21 & - \\
\hline S. brandenburg & 22 & - \\
\hline S. livingstone & 23 & 41 \\
\hline S. newport & 24 & 7 \\
\hline S. kentucky & 25 & - \\
\hline S. meleagridis & 26 & 6 \\
\hline S. minnesota & 27 & 2 \\
\hline S. azteca & 28 & - \\
\hline S. schwarzengrund & 29 & 36 \\
\hline S. tennessee & 30 & - \\
\hline S. good & 31 & 3 \\
\hline
\end{tabular}

$(31: 22)$ 


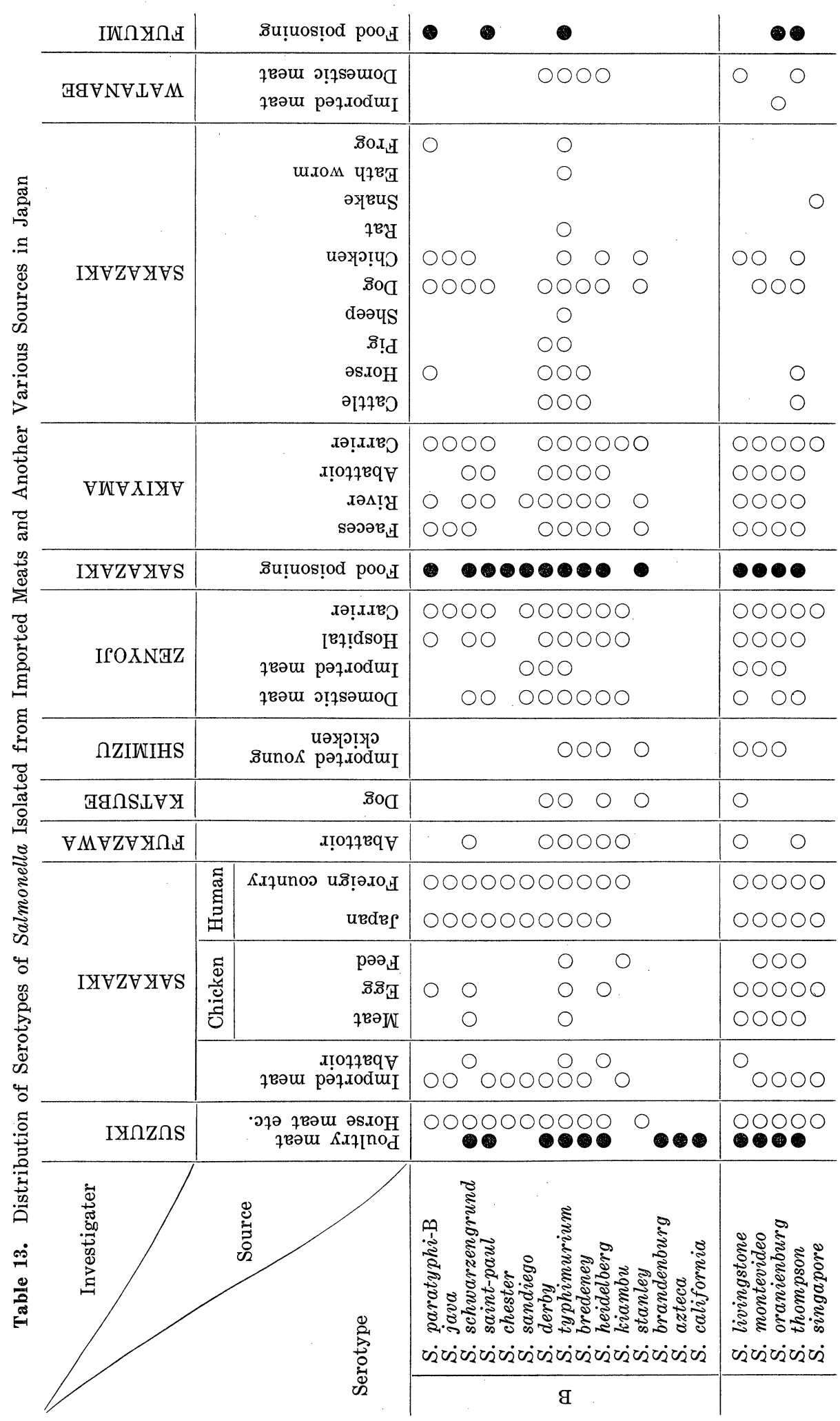




\begin{tabular}{|c|c|c|c|c|c|c|}
\hline$\bullet$ & - & - & - & - & - & \\
\hline 000 & $00^{0}$ & 0 & O & 0 & $\begin{array}{l}0 \\
0 \\
\end{array}$ & 0 \\
\hline 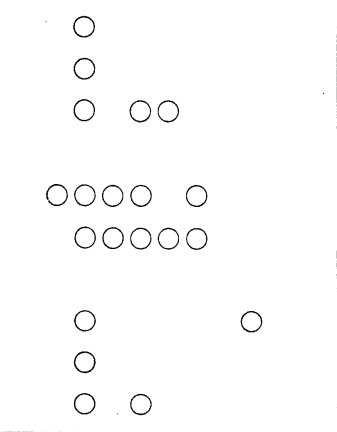 & $\begin{array}{ll}0 & \\
& 0 \\
0 & \\
0 & 0 \\
0 & 0 \\
0 & 0 \\
0 & 0 \\
& 0 \\
& 0\end{array}$ & $\begin{array}{l}0 \\
0 \\
00 \\
00 \\
00 \\
0 \\
0 \\
0\end{array}$ & $\begin{array}{rr}0 & 0 \\
0 & 0\end{array}$ & $\begin{array}{l}0 \\
0 \\
0\end{array}$ & $\begin{array}{l}0 \\
0 \\
0\end{array}$ & \\
\hline $\begin{array}{ccc}0 & 000 & 0 \\
0 & 00 & 0 \\
00 & 00 \\
0000 & 0\end{array}$ & $\begin{array}{rrr}0 & 0 & 0 \\
0 & \\
0 & 0 \\
0 & 0 & \end{array}$ & $\begin{array}{l}0 \\
0 \\
0\end{array}$ & $\begin{array}{l}000 \\
000 \\
000 \\
000\end{array}$ & $\begin{array}{ll}0 & 0 \\
0 & 0 \\
0 & \\
0 & 0\end{array}$ & $\begin{array}{ll}0 & 0 \\
0 & 0 \\
0 & 0 \\
0 & 0\end{array} \mid$ & $\begin{array}{c}0 \\
000 \\
0\end{array}$ \\
\hline - & $\bullet \bullet \bullet$ & - & - - & - & - $\quad$ & \\
\hline $\begin{array}{c}00000000 \\
00000 \\
00 \\
000\end{array}$ & $\begin{array}{cll}0 & 0 & 0 \\
0 & 0 & 0 \\
0 & 0 & 0 \\
& 0 & 0\end{array}$ & \begin{tabular}{c|}
0 \\
0 \\
0
\end{tabular} & $\begin{array}{c}0000 \\
000 \\
00 \\
0000\end{array}$ & $\begin{array}{l}00 \\
0\end{array}$ & $\begin{array}{ll}0 & 0 \\
0 & 0 \\
0 & \\
& 0\end{array} \mid$ & 0 \\
\hline 000 & 0000 & 0 & 00 & 0 & & \\
\hline 00 & 0 & 0 & 0 & & 00 & 0 \\
\hline $0 \quad 0 \quad 0$ & 0 & 0 & 0000 & 0 & 000 & 0 \\
\hline 0000000 & 00000 & 00 & 00000 & 00 & 00 & 000 \\
\hline 000000 & 0000 & $\infty$ & 0000 & 0 & 00 & \\
\hline $\begin{array}{cc}00000 & 0 \\
00 & 0\end{array}$ & 00 & $\left|\begin{array}{l}0 \\
0 \\
0\end{array}\right|$ & $\begin{array}{l}0 \\
000 \\
000\end{array}$ & $0^{0}$ & $\begin{array}{l}0 \\
0\end{array}$ & \\
\hline $0 \stackrel{00}{\circ}$ & $000^{\circ} 0$ & $\infty$ & 00000 & $\stackrel{\circ}{\circ}$ & 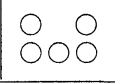 & 0000 \\
\hline 0000000 & $\begin{array}{l}00000 \\
0.00\end{array}$ & $0^{\circ}$ & 00000 & 0 & $e^{\circ 00}$ & $\begin{array}{r}0000 \\
0 .\end{array}$ \\
\hline 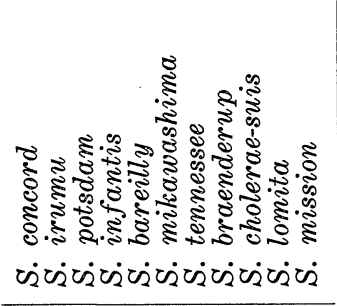 & 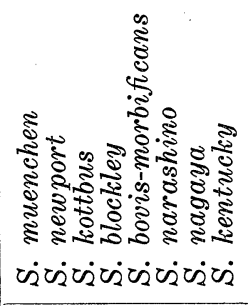 & 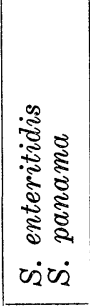 & 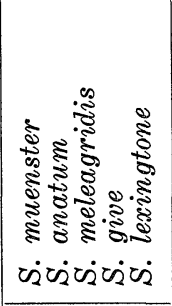 & 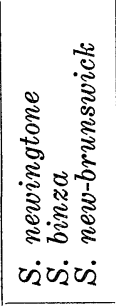 & 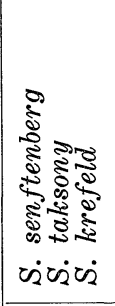 & 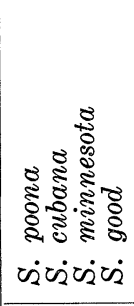 \\
\hline${ }^{\mathrm{I}} \mathrm{D}$ & ${ }^{3} \mathrm{D}$ & đ & I田 & ${ }^{8}$ H & $\sqrt{7}$ & хәчұาx $\mathrm{n}_{\mathbb{4}}$ \\
\hline
\end{tabular}


がちょら肉からは S. typhimurium の1菌型，スニッ プ肉から S. potsdam の1菌型, すずめ肉からは $S$. typhimurium と S. derby の 2 菌型がそれぞれ検出 された. S. typhimurium と S. potsdam は 3 種類 以上の肉種間に広く分布し， 2 種類以上の肉種から検出 された菌型は 9 菌型で, これらの菌はいずれも食中毒起 因菌として広く分布している菌型であった.

\section{4. 鷄肉の部位別による菌型の分布}

䳕肉の部位別による菌型の分布をみた。その結果は Table 11 に示した.

Table 14. Rank of Occurrence of Serotype of Salmonella Isolated from Imported Horse etc. and Poultry Meats

\begin{tabular}{|c|c|c|}
\hline \multirow{2}{*}{ Serotype } & \multicolumn{2}{|c|}{ Rank of occurrence } \\
\hline & $\begin{array}{l}\text { Horse etc. } \\
\text { meats }\end{array}$ & $\begin{array}{c}\text { Poultry } \\
\text { meats }\end{array}$ \\
\hline S. anatum & 1 & 2 \\
\hline S. minnesota & 2 & 27 \\
\hline S. good & 3 & 31 \\
\hline S. oranienburg & 4 & 13 \\
\hline S. sandiego & 5 & - \\
\hline S. meleagridis & 6 & 26 \\
\hline S. newport & 7 & 24 \\
\hline S. typhimurium & 8 & 3 \\
\hline S. muenchen & 9 & 18 \\
\hline S. adelaide & 10 & - \\
\hline S. montevideo & 11 & 17 \\
\hline S. saint-paul & 12 & 7 \\
\hline S. derby & 13 & 10 \\
\hline S. bredeney & 14 & 15 \\
\hline S. vartan & 15 & - \\
\hline S. taksony & 16 & - \\
\hline S. raus & 17 & - \\
\hline S. bovis-morbificans & 18 & - \\
\hline S. wandsbeck & 19 & - \\
\hline S. java & 20 & - \\
\hline S. welikade & 21 & - \\
\hline S. give & 22 & 16 \\
\hline S. potsdam & 23 & 4 \\
\hline S. orion & 24 & - \\
\hline S. rubislaw & 25 & - \\
\hline S. poona & 26 & - \\
\hline S. eastbourne & 27 & - \\
\hline S. saphra & 28 & - \\
\hline S. cubana & 29 & - \\
\hline S. zehlendorf & 30 & - \\
\hline
\end{tabular}

$(30: 14)$
表に示したように whole 25菌型, leg 24菌型, skin 12菌型, communited 8 菌型, breast 7 菌型, neck skin 6 菌型などで，各部位間に広く分布していた菌型 は, S. typhimurium, S. potsdam, S. thompson, $S$. infantis, S. anatum, S. heidelberg, S. enteritidis などで，すでに述べたように検出頻度の高い菌型ほど部 位別を問わず広く分布していた。これはその鶏肉の解体 処理場の污染状態, 分布菌型によって支配されるもので あることからむしろ当然のことである。

5. 家离肉と馬肉, カンガルー肉由来菌の菌型の比較

1) 家禽肉由来菌と馬肉など由来菌のランク

家禽肉から分離された 31 菌型が，既報の馬肉・カンガ ルー肉由来菌型の72菌型中どの順位にランクされている かをみた。 その結果は Table 12 に示した.

すなわち, 両者共通して検出された菌型は23菌型で, 家禽肉由来菌型の $74 \%$ 侄していた。 しかしそのラン クは比較的併行しているもの，いないものさまざまであ った。たと光ば，比較的併行していた菌型としては， $S$. anatum は家禽肉由来で 2 位，馬肉由来で 1 位， $S$.

Table 15. Comparison of Serotypes in Further O Group of Salmonella Isolated from Imported Horse and Chicken Meats

(1971 July 1972 Oct.)

\begin{tabular}{rl|l} 
& Horse meats etc. & Chicken meats \\
\hline 1 & S. minnesosa & S. minnesota \\
2 & S. good & S. good \\
3 & S. adelaide & \\
4 & S. vaertan & \\
5 & S. raus & \\
6 & S. wandsbek & \\
7 & S. welikade & \\
8 & S. rubislaw & \\
9 & S. poona & \\
10 & S. saphra & \\
11 & S. cubana & \\
12 & S. zehlendorf & \\
13 & S. fremantle & \\
14 & S. nottingham & \\
15 & S. shikmonach & \\
16 & S. gaminara & \\
17 & S. luke & \\
18 & S. maricopa & \\
19 & S. bukavu & \\
20 & S. uphill & \\
21 & S. champaign & \\
22 & S. langenhorn \\
23 & S. orientalis &
\end{tabular}


typhimurium は前者で 3 位, 後者で 8 位, S. kottbus は前者で 8 位, 後者で 7 位であり, 併行しなかった菌型 としては, 前者で最も高頻度に検出された S. infantis は後者では72菌型中35位に，S. potsdam は前者で 4 位，後者で23位，S. thompson は前者で 5 位，後者で 48位，S. heidelberg は前者で 6 位，後者で64位などで あった．しかしいずれの菌型をみても高頻度に検出され る菌型であってみれば，その影響はランクに関係なく同 一視すべさであると考える。

また既報の馬肉など由来菌型72菌型中の30位までの菌 型が，家禽肉由来菌ではどの順位にランクされているか をみたのが Table 14 である. 両者に共通して検出され た菌型は14菌型 $(46 \%)$ であった.

ランクが比較的併行していた菌型は S. anatum, S. typhimurium, S. saint-paul, S. derby, S.bredeney, 併行していなかった菌型はS. minnesota（前者 2 位, 後者27位), S. good (前者 3 位, 後者31位), $S$. meleagridis (前者 6 位, 後者 26 位), S. newport (前 者 7 位, 後者 24 位), S. potsdam (前者23位, 後者 4 位) などであった。

\section{2）その他の群に属する菌型の比較}

既報に馬肉やカンガルー肉由来菌型の特徵の一つに, その他の群に型別されるものが約 $20 \%$ 認められたことを 指摘した。 そこで今回の家禽肉由来菌でその他の群に型 別される菌型とどのような相違が認められるか否かにつ いて比較検討した。 その結果は Table 15 に示した。

表に示したよらに，馬肉などからは S. minnesota， S. good, S. adelaideをはじめ23菌型がこの群に属して いたのに対し, 家禽肉からはS. minnesota, S. good の 2 菌型であった. 既報の馬肉 (アルゼンチン), カン ガルー肉（オーストラリア）がいずれも野生のものを主 として補穫したものであることを考えると, その他の群 に属する菌型は, それらの国々の在野性のものに比較的 多く分布している菌型であるのかも知れない.

また S. minnesota, S. good は馬肉, カンガルー肉, 家禽肉いずれの系からも高頻度に検出されているにもか かわらずいまだ我が国に扣いて食中毒起因菌としての報 告例がないところから ${ }^{13)}$ 本菌は人に対する起病性が他の 菌型のものとは異なるためではないかと考えられる。こ の点に関して渡辺 $\left.{ }^{9} \sim 11\right)$ らも同様の考方方の上に立って マウスに対する病原性の有無によってその起病性の相違 をみつけようと試みたが，S. typhimurium と $S$. good では同等量の菌量によってマウスをへい死させ, 従来一般的に採用されてきた実験動物による方法では不 適当であり, サルモネラの起病性に関する実験方法の再 検討の必要性を強調している.

\section{6. 輸入食肉由来菌型の分布と我が国における各種由 来菌型の分布の比較}

我々が過去数年にわたって, 輸入食肉から検出分離し
た菌型と，我が国においてすでに多くの研究者によって 国内の各種の検体から検出分離された菌型とを比較検討 した。その結果は Table 13 に示した。

輸入食肉から検出分離された菌型は72菌型に及ぶが, そのらちすでに他の研究者によって過去に我が国で検出 分離された菌型は約50菌型であった。そして現在までに 食中毒菌として報告された菌型は33菌型6)，13)，14，27) であ った。

最も多くの系列から検出分離されたものを順に示す 之, S. typhimurium, S. enteritidis, S. potsdam, S. senftenberg, $S$. thompson, S. oranienburg, $S$. infantis, S. anatum, S. derby, S. give, S. blockley, S. heidelberg などであるが，そのほとんどが我が国で 過去に食中毒菌として報告されたことのある菌型であっ た。このように広範囲の検体から高頻度に検出される傾 向のある菌型ほど定着性の強いことを意味し，食中毒起 因菌之しての可能性が高い28) と考えられる.この点は今 後, 輸入食肉などによって搬入される菌型の推移とそれ らの菌型の我が国への定着の状態を見守ることにより， 新しい菌型によって起こり得る可能性を予測することが できると考えられ，本菌による食中毒予防の上からも重 要な手掛かりを与えるものと確信する.

輸入食肉などから検出分離された 菌型の約 $80 \%$ 以上 は，すでに我が国に定着しているものと考えられ，しか も将来にわたって食中毒起因菌として，実害を及ぼす傾 向はますます高まるものと考えられる。

最近サルモネラに対する関心が再び高まり，古くて新 しい問題としていろいろの学会などでも取り上げられ， その結論として，サルモネラに対する広範かつ万全の防 止対策を早急に樹立すべきであると強調されている，誠 に当然のことでその一翼をになっている輸入食品のサル モネラ検査とその結果に対する行政処置は，一段と厳重 にすべきであることを痛感した。

\section{結論}

我々は，1971から1972年にかけて15か月間に輸入家昺 肉1903ロット，6523 検体についてサルモネラ検查を行 い, 次のような結果を得た。

1. 輸入家禽肉のサルモネラ污染率は, 輸入国別, 家 禽の種類別などによって異なるが，平均污染率は検体別 で10.3\%，ロット別で24.2\%であった。

2. 輸入国別にみると，ニュージーランド $(44.4 \%)$, オランダ $(28.5 \%)$ ，フランス $(26.7 \%)$ のように污染 率の高いもの，デンマーク $(3.8 \%)$ のように低いもの， アメリカ $(10.7 \%)$, 中国 $(9.3 \%)$ のように前 2 者の中 間に位するものなど輸入国により污染率はまちまちであ った.

3. 家禽の種類別では, 鶏肉の污染率の平均は $10.3 \%$, その他の家禽肉では10.6\%であった。

4. 鶏肉の部位別の污染率は communited (すり身の 
くず肉）が約60\%で最も高率であった.

5. 分離菌の $\mathrm{O}$ 血清による群別と菌型では， $\mathrm{C}_{1}$ 群 $(42.8 \%), \mathrm{B}$ 群 $(29.0 \%), \mathrm{E}$ 群 $(15.8 \%)$ で32菌型が検 出され, そのちち S. infantis, S. typhimurium, S. anatum, S. potsdam, S. thompson, S. heidelberg, S. saint-paul, S. kottbus, S. enteritidis などの菌 型の検出頻度が高く, 馬肉, カンガルー肉などの菌型パ ターンと明らかに異なっていた。

6. 輸入国の属する大陸別にその菌型パターンをみる と, アメリカ大陸からのもの（アメリカ型）とヨーロッ パ大陸からのもの（ヨーロッパ型）は比較的よく類似し ていたが，中国大陸からのもの (中国型) は明らかに前 二者と異なっていた。

この調查研究に当たり終始御指導御鞭達を賜った前国 立衛生試験所衛生微生物部長岩原繁雄博士ならびに国立 予防衛生研究所圾崎利一博士に深謝するとともに試料収 集に御協力を賜った東京, 神戸, 小樽, 大阪, 横浜各港 の厚生省駐在官の各位に感謝の意を表します。

\section{文献}

1) 鈴木 昭, 河西 勉, 鈴木君代, 岩田夏江, 高山 澄江：衛生試報. 85, 188 (1967).

2) 鈴木 昭, 河西 勉, 小沼博隆：同上, 89, 125 (1971).

3) 鈴木 昭: メディアサークル, 14, 306 (1969).

4) 鈴木 昭：同上, 15, 425 (1970).

5) 坂崎利一：モダンメディア，13，455 (1967).

6) 善養寺 浩: メディアサークル, 12, 437 (1967).

7) 善養寺 浩：日本公衛誌. 16, 680 (1969).

8) 善養寺 浩: 同上, 16, 729 (1969).

9) 渡辺昭宜, 沖浦加智子, 檜山 充, 加藤敏忠, 野 口謹一, 織田利昭：日獣会誌. 23, 275 (1970).

10）渡辺昭宜, 沖浦加智子, 栗栖 誠: 同上, 24, 186 (1971).

11）渡辺昭宜, 栗栖 誠, 徳丸雅一, 雨宮一彦: 同 上, 26, 240 (1973).
12）佐藤儀平：鶏病研究会報，7, 111 (1971).

13) 坂井千三： メディアサークル，14，315 (1969).

14) 福見秀雄: The World Problem of Salmonellosis, edited by E. Van Oye 507 (1964).

15）厚生省編：微生物検查必携, 日本公衆衛生協会.

16) N. C. D. C. U. S. Pep. Hlth. Edu. and Welfare: Salmonella Surveillance, Annual Summary, 1964, 1965, 1966, 1967, 1968.

17) 竹内一豊: 食品衛生研究, 15, 3 (1965).

18) Khera, S. S.: Indian J. Med. Res., 50, 569 (1962).

19) Sharman, S. P., Singh, C. M.: Indian J. Microbiol 3, 13 (1963).

20) Rasmussen, P. G.: Nord. Vet. Med., 14, 39 (1962).

21) Sadler, W. W., Corstvet, R. E.: Appl. Microbiol., 13, 348 (1965).

22) Grumbles, L. D., Flowers, A. J.: J. Am. Vet. Assoc., 138, 261 (1961).

23) Newell, K.W.: J. Hyg., 57, 92 (1959).

24) Elleman, G.: Nord. Vet. Med., 11, 607 (1959).

25) Sader, W. W., Yamamoto, R., Adler, H. E., Stewart, G. H.: Appl. Microbiol., 9, 72 (1961).

26) Prost, C. E., Rieman, H.: An. Rev. Microbiol., 21, 495 (1967).

27）坂崎利一：メディアサークル，14，245 (1967).

28) 坂井千三, 伊藤 武, 津野正朗, 丸山務, 岡沢 久美子, 善養寺 浩：日本食品衛生学会第 25 回 学術講演会発表 (東京) (1973).

29）橋本秀夫： メディアサークル，14，346 (1969).

30) 秋山昭一: 同上, 14, 339 (1969).

31) 仲西寿男: 同上, 14, 291 (1969).

32) 佐藤儀平: 同上, 14, 1 (1969).

33) 斉藤 誠: 同上, 11, 139 (1966). 